\title{
Assessment of Undiscovered Oil and Gas Resources of Libya and Tunisia, 2010
}

Using a geology-based assessment methodology, the U.S. Geological Survey estimated means of 3.97 billion barrels of undiscovered oil, 38.5 trillion cubic feet of undiscovered natural gas, and 1.47 billion barrels of undiscovered natural gas liquids in two provinces of North Africa.

\section{Introduction}

The U.S. Geological Survey (USGS) assessed the potential for undiscovered conventional oil and gas fields within two geologic provinces of North Africa-Sirte Basin in Libya and Pelagian Basin in Tunisia and western Libya-as part of the USGS World Petroleum Resources Project (fig. 1). The Sirte Basin originated as a Cretaceous rift that evolved into a post-rift basin dominated by thermal subsidence; it is characterized by carbonate deposition on high blocks and fine-grained clastic deposition in troughs (Ahlbrandt, 2001; Hallett, 2002). The Pelagian Basin was dominated by Mesozoic and Cenozoic subsidence related to tectonism along the northern margin of the African plate (Klett, 2001).

One total petroleum system (TPS) was defined in the Sirte Basin Province, and two TPSs were defined in the Pelagian
Basin Province. The Sirte-Rachmat Composite TPS in the Sirte Basin Province contains the post-rift Coniacian-Campanian Sirte-Rachmat organic-rich shale/marl, which was deposited in troughs across the Sirte Basin during the early phase of thermal subsidence (Ahlbrandt, 2001; Hallett, 2002). Major reservoirs in the Sirte Basin Province include syn-rift continental sandstones and post-rift shallow-marine carbonates, with shales and evaporites acting as seals for hydrocarbon reservoirs (Ahlbrandt, 2001; Hallett, 2002). Two assessment units (AU) were defined within the Sirte-Rachmat Composite TPS: the Onshore Sirte Carbonate-Clastic AU and the Offshore Sirte Basin AU.

Within the Pelagian Basin, two TPSs as defined by Klett (2001) were retained for this assessment. The Jurassic-Cretaceous Composite TPS consists of fluids from Jurassic and Cretaceous deep-marine shales that migrated into Jurassic-Cretaceous shallow marine limestones and Upper Cretaceous fractured deepwater chalks. Seals include Jurassic and Cretaceous shales and evaporites. One AU was defined for this TPS, the Jurassic-Cretaceous Structural/Stratigraphic AU, based on Klett (2001). The Bou Dabbous Cenozoic TPS contains the Eocene Bou Dabbous organic-rich shale, with hydrocarbons that migrated into lower and middle Eocene shallow-water limestones that are sealed by

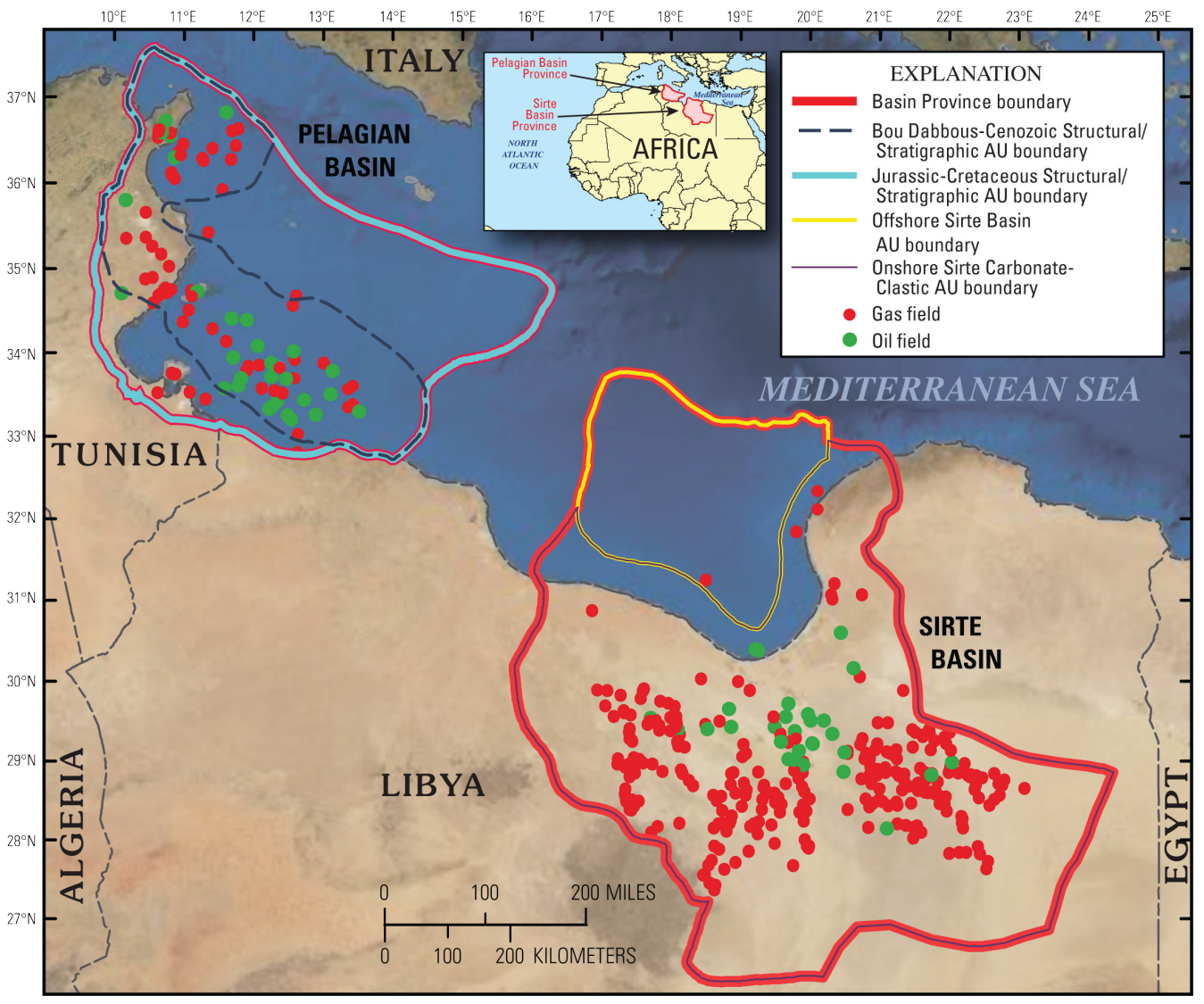

Figure 1. Locations of the Sirte and Pelagian Basin Provinces, North Africa. AU, assessment unit. 
overlying shales and marls. This TPS contains the Bou DabbousCenozoic Structural/Stratigraphic AU, as defined by Klett (2001).

The methodology for the assessment included a complete geologic framework description for each province, based mainly on published literature and the definition of petroleum systems and assessment units within these systems. Exploration and discovery history was a critical part of the methodology used to estimate sizes and numbers of undiscovered accumulations. In areas where there are few or no discoveries (for example, offshore Sirte Basin), geologic analogs were used as a basis for estimating volumes of undiscovered oil and gas resources. Each assessment unit was assessed for undiscovered oil and nonassociated gas accumulations, and coproduct ratios were used to calculate the volumes of associated gas (gas in oil fields) and natural gas liquids.

\section{Resource Summary}

The USGS assessed undiscovered conventional oil and gas resources within the three TPSs in the Sirte and Pelagian Basin Provinces (table 1). The mean total of undiscovered oil in these two provinces is 3,974 million barrels of oil (MMBO), with a range from 1,119 MMBO (95 percent probability) to 9,044 MMBO (5 percent probability); for undiscovered gas the mean total is 38,509 billion cubic feet of gas (BCFG), with a range from 11,520 to 84,347 BCFG; and the mean total for natural gas is 1,466 million barrels of natural gas liquids (MMBNGL), with a range from 405 to 3,384 MMBNGL.

About 90 percent of the mean total of undiscovered oil (3,545 MMBO), 85 percent of the mean total of undiscovered gas $(32,451 \mathrm{BCFC})$, and 89 percent of the mean total of undiscovered natural gas liquids (1,298 MMBNGL) are estimated to be in the Sirte Basin Province. Of these volumes, 64 percent of the undiscovered oil (2,267 MMBO), 80 percent of the undiscovered gas $(25,609 \mathrm{BCFG})$, and 78 percent of the undiscovered natural gas liquids (1,010 MMBNGL) are in the Offshore Sirte Basin $\mathrm{AU}$, with the remaining percentages in the Onshore Sirte Carbonate-Clastic AU. The higher percentage of undiscovered oil and gas resources assessed in the Offshore Sirte Basin AU reflects the relatively underexplored history of this part of the Sirte Basin Province.

Overall, the assessment indicates that (1) 80-90 percent of the undiscovered oil and gas resources are in the Sirte Basin Province, (2) there is significantly more total undiscovered gas resource in both provinces $(38,509 \mathrm{BCFG}$ or $6,640 \mathrm{MMBOE})$ than total undiscovered oil resource (3,974 MMBO), and (3) there is almost twice as much undiscovered gas $(25,609$ BCFG or 4,415 MMBOE) in the Offshore Sirte Basin AU as there is undiscovered oil (2,267 MMBO).

\section{References Cited}

Ahlbrandt, T.S., 2001, The Sirte Basin Province of Libya-SirteZelten total petroleum system: U.S. Geological Survey Bulletin 2202-F, 29 p., http://geology.cr.usgs.gov/pub/bulletins/b2202-f/.

Hallett, Don, 2002, Petroleum geology of Libya: Amsterdam, Elsevier Inc., 503 p.

Klett, T.R., 2001, Total petroleum systems of the Pelagian Province, Tunisia, Libya, Italy, and Malta-The Bou Dabbous-Tertiary and Jurassic-Cretaceous Composite: U.S. Geological Survey Bulletin 2202-D, 27 p., http://geology.cr.usgs.gov/pub/ bulletins/b2202-d/.

\section{For Further Information}

Supporting studies of the geologic models and the methodology used in the assessment of North Africa basins are in progress. Assessment results are available at the USGS Central Energy Resources Science Center website, http://energy.cr.usgs.gov/ oilgas/.

\section{North Africa Assessment Team:}

Katherine J. Whidden (Task Leader, kwhidden@usgs.gov), Michael Lewan, Christopher J. Schenk, Ronald R. Charpentier, Troy A. Cook, Timothy R. Klett, and Janet Pitman.

Table 1. Libya and Tunisia assessment results.

[MMBO, million barrels of oil. BCFG, billion cubic feet of gas. MMBNGL, million barrels of natural gas liquids. Results shown are fully risked estimates. For gas accumulations, all liquids are included as NGL (natural gas liquids). Undiscovered gas resources are the sum of nonassociated and associated gas. F95 represents a 95 -percent chance of at least the amount tabulated; other fractiles are defined similarly. Largest expected oil field in MMBO; largest expected gas field in BCFG. TPS, total petroleum system; AU, assessment unit. Gray shading indicates not applicable]

\begin{tabular}{|c|c|c|c|c|c|c|c|c|c|c|c|c|c|c|}
\hline \multirow{3}{*}{$\begin{array}{l}\text { Total petroleum systems } \\
\text { (TPS) } \\
\text { and assessment units (AU) }\end{array}$} & \multirow{3}{*}{$\begin{array}{l}\text { Field } \\
\text { type }\end{array}$} & \multirow{3}{*}{\begin{tabular}{c|} 
Largest \\
expected \\
mean \\
field size
\end{tabular}} & \multicolumn{12}{|c|}{ Total undiscovered resources } \\
\hline & & & \multicolumn{4}{|c|}{ Oil (MMBO) } & \multicolumn{4}{|c|}{$\operatorname{Gas}(B C F G)$} & \multicolumn{4}{|c|}{ NGL (MMBNGL) } \\
\hline & & & F95 & F50 & F5 & Mean & F95 & F50 & $\mathrm{F5}$ & Mean & F95 & $\mathrm{F50}$ & F5 & Mean \\
\hline \multicolumn{15}{|l|}{ Sirte-Rachmat Composite TPS } \\
\hline \multirow{2}{*}{$\begin{array}{l}\text { Onshore Sirte Carbonate- } \\
\text { Clastic AU }\end{array}$} & Oil & 432 & 364 & 1,087 & 2,823 & 1,278 & 418 & 1,338 & 4,035 & 1,673 & 22 & 74 & 240 & 96 \\
\hline & Gas & 2,042 & & & & & 1,267 & 4,179 & 12,569 & 5,169 & 44 & 151 & 478 & 192 \\
\hline \multirow{2}{*}{ Offshore Sirte Basin AU } & Oil & 857 & 563 & 1,838 & 5,457 & 2,267 & 633 & 2,250 & 7,677 & 2,972 & 34 & 124 & 454 & 170 \\
\hline & Gas & 6,843 & & & & & 6,591 & 19,540 & 49,077 & 22,637 & 233 & 709 & 1,903 & 840 \\
\hline \multicolumn{15}{|l|}{ Bou Dabbous-Cenozoic TPS } \\
\hline \multirow{2}{*}{$\begin{array}{l}\text { Bou Dabbous-Cenozoic } \\
\text { Structural/Stratigraphic AU }\end{array}$} & Oil & 60 & 130 & 283 & 552 & 305 & 45 & 113 & 274 & 131 & 1 & 3 & 8 & 4 \\
\hline & Gas & 616 & & & & & 1,443 & 2,933 & 5,405 & 3,119 & 37 & 75 & 140 & 80 \\
\hline \multicolumn{15}{|c|}{ Jurassic-Cretaceous Composite TPS } \\
\hline \multirow{2}{*}{$\begin{array}{l}\text { Jurassic-Cretaceous } \\
\text { Structural/Stratigraphic AU }\end{array}$} & Oil & 13 & 62 & 116 & 212 & 124 & 79 & 154 & 287 & 165 & 2 & 4 & 7 & 4 \\
\hline & Gas & 569 & & & & & 1,044 & 2,409 & 5,023 & 2,643 & 32 & 73 & 154 & 80 \\
\hline $\begin{array}{l}\text { Total conventional } \\
\text { resources }\end{array}$ & & & 1,119 & 3,324 & 9,044 & 3,974 & 11,520 & 32,916 & 84,347 & 38,509 & 405 & 1,213 & 3,384 & 1,466 \\
\hline
\end{tabular}

